\title{
GENDER AND IDENTITY IN THE SLOVAK AND SERBIAN PHRASEOLOGY
}

\begin{abstract}
Our paper is based on the indissoluble relationship between gender, identity and language determinism, which are perfectly reflected in phraseology. The methodological approach is derived from Dolník's theory of cultural identity as a set of mentefacts, sociofacts and artefacts. Language as part of culture and implicitly part of identity becomes an instrument by which people can interpret the world in which they live, leading to linguistic determinism. In addition, the components of cultural identity overlap not only with the stages of individual language development, but also with the stages of phrasemes' development. Based on the relationship between individual identity, cultural collective identity, language determinism, and phrasems' development, considering that cultural memory involves language memory (Dolník, 2010: 93), we can infer that gender issues are faithfully reflected in phraseology. It applies to both Slovak and Serbian as Slavic languages, whose phraseologies reflect their pride and prejudice in identity and gender-related issues.
\end{abstract}

Key words: gender, identity, mentefacts, sociofacts, artefacts.

\section{Methodological approach}

Our paper is based on the indissoluble relationship between gender, identity and language determinism, all being perfectly reflected by phraseology. Identity is defined as a complex including physical, social and psychological components. The physical characteristics refer to sex, countenance, moles, finger prints, physical handicaps etc.. The social component refers to the roles people play in their personal, work and social life, while the psychological one represents individual personality-related characteristics (Nakonečný, 2009: 353). At the macrolevel, the cultural identity includes mentefacts, sociofacts and artefacts. The mentefacts represent ideas, opinions, convictions, values, prejudices, stereotypes and myths related to the relationship with nature, the social hierarchy, justice, the meaning of life and death, morality, aesthetic taste, the relationship between the individual and the group they belong to. The sociofacts represent institutions in terms of social anthropology and cultural sociology, which is structures acting

\footnotetext{
${ }^{1}$ marilena_tiprigan@yahoo.com
} 
in various fields of the social life such as Christmas and Easter. The artefacts represent the material cultural constructs as part of civilization (Dolník, 2011: 57-61). In this equation, language as part of culture and implicitly part of one's identity becomes the instrument by which people can interpret the world they live in, which means that it determines the degree of people's dependence on language in terms of language determinism.

From this perspective, there is a tight relationship between the three components of one's identity, the stages of their development, the language determinism and the evolution of phrasemes. The physical component of one's identity is related to the early stage of their physical development, characterized by language acquisition and free association of lexemes (the very origin of phrasemes). This is the stage marked by language determinism, when people simply accept and assume language as a given fact. The social component characterizes the later stage of social development, when, thanks to education, people can act, react and interact through language. This is the stage marked by relative language freedom, when linguistically educated people accept and assume language as a property they acquired from their forefathers, depositors of the ancestral spiritual legacy, and are ready to enrich it by their own contribution. It is at this stage that we witness phrasemes' semantic transformation and petrifaction. Last, but not least, the psychical component represents the peak of the psychological development, marked by language autonomy, when people are capable of making full use of the language potential, they grow to manipulate language to its utmost potential and even to master through language. This stage also corresponds to the latest stage in phrasemes' development, when qualitative and quantitative variants of phrasemes are generated. For instance, for a child in its early stage of physical development, characterized by language acquisition, the only means of communication is the free association of words based on their mimetic capacity. In other words, a child would limit itself to simply utter the basic words to make itself understood by the others; byt "to be" and nálada "mood" would probably suffice to communicate what their state of mind is like at the moment. The mimetic principle is also valid for the early stage in phrasemes' development, when, based on comparisons, metaphors, metonymies; people simply resort to free associations of words. In the later stage of social development, thanks to education, people transform the free associations of lexemes in petrified syntactic units; they link the verb to the noun phrase (byt' $v$ nálade "to be in a mood". Finally, as adults endowed with creativity, people manipulate language according to their needs. It corresponds to the third stage in phrasemes' development, when they undergo quantitative or qualitative modifications (byt'v dobrej/ zlej nálade "to be in a good/ bad mood").

In a life time cycle, people experience all the three stages in various degrees: as children, they are subject to the pressure of language acquisition, as educated adults they face the necessity to take over language as part of their ownership and to enrich it, and as creative individuals they are linked to various 
forms of language use while aiming at linguistic freedom (Dolník, 2010: 28-32). There obviously is a parallelism between the physical, social and psychological components of people's identity and the degree of their dependence on language. In the earlier stages of their physical development, people are focused on language acquisition. During their social development as a very result of education, people make use of their ability to react to social standards through language. Finally, as fully developed personalities having reached the peak of their psychological development, people are capable of manipulating language and making creative use of it.

At the same time, as we have already mentioned, phrasemes' development phases overlap with identity's components. The physical component of human identity corresponds to the early stage of their physical development, characterized by language acquisition just like phrasemes that originally represent free associations of lexemes. The social component of identity corresponds to the second stage, i. e. the social development, characterized by social interaction, action and reaction through language, which matches with that stage in phrasemes' development when free associations of words undergo semantic transformation and petrifaction, acquiring new features such as: formalism, expressiveness due to the fact that their constituent elements are joined together based on metaphors, metonymies, antithesis etc., standardization due to the fact that they are meant to serve the functions of the language in well defined situations, perceived as "social rituals". Finally, the psychical component of human identity as fully reflected in creativity corresponds to the late stage of language development characterized by people's making full use of the language potential in the attempt to reach linguistic autonomy, manipulating various language forms and registers, which corresponds to the third potential stage in phrasemes' development, characterized by quantitative and qualitative variants of the same phraseological unit.

Coming back to Dolník's theory of cultural facts as part of identity at the macrolevel, we can affirm that phrasemes, too, are cultural facts perceived as a complex of mentefacts, sociofacts and artefacts. Phrasemes are mentefacts because they do mirror people's ideas, opinions, convictions, values, prejudices, stereotypes and myths. Moreover, phrasemes are sociofacts because they are standardized as the very result of individual's process of accommodation and assimilation and they therefore become part of social rituals confirming various functions of the language. At the same time, phrasemes are artefacts reflecting the material cultural legacy as part of civilization (Dolník, 2011: 57-61). At the level of mentefacts, phrasemes implicitly reflect the language determinism, by virtue of which people simply accept and assume them as a given fact. At the level of sociofacts, phrasemes represent an item of property people acquired from their forefathers as depositors of the ancestral spiritual legacy through education, which insures continuity and gives room to potential enrichment. At the level of artefacts, phrasemes represent creativity and freedom to manipulate language to 
its utmost potential, which often leads to quantitative or qualitative modifications of the initial phrasemes as in the above mentioned example.

Based on these parallelisms between individual identity, cultural collective identity, on the one hand, and language determinism and phrasemes' evolution on the other hand, taking into consideration that cultural memory includes linguistic memory (Dolník, 2010: 93), we can infer that gender issues are faithfully reflected in phraseology. It also applies to Slovak, a predominantly West Slavic flective language, which phraseology reflects the Slovak pride and prejudice in gender related issues.

\section{The Slovak tradition vs. the Czech tradition}

In the Slovak linguistic tradition, there are practically no theoretical studies on gender as regarded from the socio-linguistic perspective. Actually, there is not even a specific term referring to gender in terms of social dimension of the biological sexual identity. In the Czech linguistics, gender and gender strategies have a longer tradition, aiming at founding a new linguistic discipline with its own terminology, methodology and specific gender topics. S. Čmejrková (Čmejrková, 2005: 187) for instance coins the term of "gender" and suggests that it should be used as such in the Czech linguistics: "Pojem gender, definovaný jako kulturní interpretace biologické danosti pohlaví a vystihujíci dnes stále častěji kontradikci mezi př́rodou či biologií a společností či kulturou je chápán jako výsledek sociálního konstruování." (The concept of gender, defined as a cultural interpretation of the biological nature of sex and describing more and more often the contradiction between nature or biology and society or culture is understood as the result of social construction.). The Czech linguist also makes a clear distinction between the structuralist and the poststructuralist interpretation of gender as a grammatical category. If structuralists considered the masculine grammatical gender to be the unmarked member of the opposition, while the feminine grammatical gender was the marked one, being subordinated to the masculine that has not only the specific grammatical meaning, but also a generic, neutral meaning denoting human beings in general, poststructuralists endeavor to reconsider the patriarchal paradigm and to increase women's visibility (Čmejrková, 2005: 188).

\section{Gender and identity in the Slovak and Serbian phraseology}

In our paper, we shall focus on the Slovak phraseology, where people are aimed at and are therefore implicitly assessed, which means that we may expect phraseology to mirror Slovak pride and prejudice the best. All the examples we 
chose were taken from Frazeologický slovnik. Človek a príroda vo frazeológii "The Phraseological Dictionary. Individual and Nature in Phraseology", which authors are Katarína Habovštiaková and Ema Krošláková, from Mile Tomici’s Romanian-Serbian Phraseological Dictionary, Otašević's Frazeološki rečnik and Vuk's Srpske narodne poslovice. The equivalence of the Serbian phrasemes was validated by professor Octavia Nedelcu from the University of Bucharest and Jelena Pavlović from the University of Kragujevac.

\section{Kindness}

What do they understand by mental and character features? First of all, it is about kindness, which is closely related to spiritual symbols like heart, soul, angel, but also to basic words reflecting everyday needs like bread, sugar, for example: Sk: Je samá dobrota. "He / she is all good." Sk: Je ako kus chleba (ako kus cukru). "He / she is like a piece of bread (like a piece of sugar)." cf. Sb: Dobar kao hleb / Na hleb da ga mažeš."As good as bread / Good to anoint on bread" (Otašević Dobar kao dobar dan "As good a good day", Dobar kao duša "As good as a soul") (Dobar kao dobar dan u godini, Vuk, 71 "As good as a good day of the year"); Sk: To je človek dobrého srdca (človek mäkkého srdca). "He / she is a good-hearted person (a soft-hearted person)." cf. Sb: Čovek dobrog srca, On ima dobro srce "a good-hearted person", "He has a good heart." Sk: Má (zlaté) srdce. "He / she has a (golden) heart." cf. Sb: Zlatno srce, Imati zlatno srce, Imati veliko srce. "a golden heart, to have a golden heart, to have a big heart" Sk: Má srdce na pravom mieste. cf. Sb: Srce mu je na mestu. "He / she has their heart in the right place." Sk: Ten by srdce na dlan̆ vyložil. "He / she would place their heart on one's palm." cf. Sb: Dati srce na dlanu, Pružiti srce na dlanu. "to place one's heart on one's palm." Sk: Dušu by dal zo seba. "He / she would give their own soul." cf. Sb: Dati dušu za nekoga "to give one's soul for somebody else. Sk: "Dobrý ako anjel. "As good as an angel." cf. Sb: (Otašević Dobar kao anđeo "As good as an Angel"). On the contrary, the Slovaks say about a bad person that Sk: Nemá srdce. "He / she does not have a heart." cf. Sb: Nema srca. "He / she does not have a heart.", Biti kamenog srca. "to be a stone-hearted person", Bez duše. "to have no soul" Bezdušan. "a soulless person" Hladnog srca. "to be a cold-hearted person" Imati hladno srce. "to have a cold heart" or Sk: Je horši od čerta (od satana). cf. Sb: Gori je od Sotone "He is worse than Satan" / Zao / pakostan kao vrag "Evil / sinful as the Devil"; Sk: Lucifer z pekla. "Lucifer from hell." cf. Sb: Sotona, Đavo "Satan, Devil". Most of these phrasemes are phrased as sententious, gnomic reflections of general character that are equally valid for men and for women. Yet, in some cases, they aim exclusively at men, especially when it comes to (lack of) characteristics suggesting their (lack of) manliness, such as: transgressing the principles of morality, sinning, worshipping the devil 
(Sk: Zapisal dušu čertovi. cf. Sb: Prodati/dati/zavetovati/zaveštati dušu đavolu "He sold his soul to the devil.") or keeping his word (Sk: Slovo robi muža. "A man always keeps his word." cf. Sb: Držati reč. "to keep one's word", Biti od reči "to be a person of word", Vo se veže za rogove, a čovek za jezik. (Vuk, 46) "The ox shall be held by horns and the man shall keep his word"). Thus, in the Slovak culture, man becomes the warrant of the moral principles and is expected to re-make the biblical image of the pure Adam. In other words, being a man means keeping one's word, not transgressing the moral principles, not sinning, not worshipping the devil, but being like Adam in the Heavens before the Fall. Morality has therefore a deeply religious meaning in the Slovak phraseology, which only confirms that man, and not woman, that Adam, and not Eve is the warrant of the moral principles. This is why man is exponential in the Slovak phraseology.

\section{Stupidity}

When it comes to negative characteristics like stupidity and foolishness, there are gender variants: the woman Sk: je hlúpa (sprostá) ako hus. "She is as stupid as a goose." cf. Sb: Glupa kao guska "She is as stupid as a goose.", Guska "a goose", Tri žene i jedna guska čine vašar (u vojvodstvu, Vuk, 403) "It takes three women and a goose to make up a fair (in the voivodeship)". As for the man, he is Sk: je hlúpy (sprostý) ako basa (ako tík, ako trúba, ako poleno, ako baran, ako barani roh, ako tel'a, ako čízik). "He is as stupid as a bass (as a beater, as a trumpet, as a log, as a ram, as a ram's horn, as a calf, as a siskin)". cf. Sb: Glup kao klada / kao cepanica / kao noć / kao kokoš / kao vo / kao đuskija / kao guzica / kao duduk / kao balvan "as stupid as wood / as a splinter / as night / as a hen / as a bull / as an ass / as a boulder". In both cultures, male-related variants are much more numerous than the female ones, which shows that man's flows are fined in more various ways. In certain cases, in Slovak, there are only male-related phrasemes with no female correspondent, such as: Sk: To je (starý) blázon. "This is a (an old) fool.", Sk: Hlupy Jano. "Foolish Jano". In other cases, stupidity is related to the lack of talent in male specific jobs such as trade: Sk: Hlúpy všetko kúpi. "A fool buys everything.", Sk: Hlúpy zle kúpi. "A fool makes bad deals.", Sk: Hlúpy chytro kúpi, neskoro predá. "A fool buys fast and sells late." These phrasemes suggest that it is easy for men to fall into unhappiness due to their carelessness, but rather difficult to escape from it, which implies that men's carelessness and shallowness make them vulnerable in front of temptations, which means that their own stupidity, and not Eve is to blame for their sinning and disrespect of the moral principles. 


\section{The relationship between man and woman}

When it comes to devotion and trustfulness, the other term of comparison is one of the family members, e. g.: Verí mu ako vlastnému bratovi. cf. Sb: Veruje mu kao (rođenom) bratu. "He/ she trusts him as if he had been his/ her own brother.", Sk: Spolieha sa naňho ako na vlastnú mat'. "He/ she relies on him as on his/ her own mom." cf. Sb: Pouzda se u njega (veruje mu) kao samom sebi. "He / she trusts him (believes in him) as in himself / herself." It means that the Slovaks perceive family as a symbol of reliability, devotion and trustfulness, which also implies order, cohesion, and closeness. Masculine and feminine principle are in harmony only within family and family relationships.

In certain cases, man and woman are pictured as being complementary: Sk: Kam chlap nemôže, dôjde žena. "A woman can do what a man can't." Yet, in most of the cases, the female principle is represented as the malicious one: Kam (kde) čert nemôže, pošle starú babu. "The Devil will send a spinster wherever he can't manage by himself." cf. Sb: Đe đavo ne može što svršiti onđe babu pošalje. (Vuk, 88) "The Devil will send an old woman wherever he can't manage by himself." The woman is related to the image of the spinster, a symbol of frustration, of failure and therefore of utmost malice, associated with the Devil itself, symbol of disorder, division and physical and moral dissolution. Due to its hermaphroditism, the Devil is the embodiment of ambivalence: it is only Lucifer, the light holder that can turn into the Prince of Darkness (Chevalier, Gheerbrant, 1994: 443-445). The spinster becomes the Evil itself as against the ambivalent Devil, hence the amplification of the negative side of woman's perfidy. Last, but not least, Ani čert nevymyslí, čo má žena vo svojej mysli. cf. Sb: Čak ni đavo ne misli, što žena ima u glavi. "Not even the Devil can think of what a woman has in her mind.", which means that a woman overpasses the Devil itself in cunning and perfidy. Thus, there is a threefold gradation in the perception of female's cleverness and cunning: man and woman are in harmony, man and woman are complementary, and the woman (the spinster or the old woman) can compete with the Devil itself and even overpasses it.

\section{Poverty}

For the Slovaks, poverty is related to Good God's will. Since people are at His mercy, poverty is part of their human condition, it is a sort of fatalism people can hardly escape from, e. g.: Sk: Riedkou plachtičkou ho Pán Boh prikryl. "Lord God covered him with a small canvas." Sometimes, poverty is regarded as a temporal and local constant value, e. g.: Sk: Bohatstvo len dočasu a chudoba naveky. "Wealth is only temporary and poverty forever." Sk: I vo Viedni l'udia biedni. "Even in Vienna people are miserable.", I v Pešti bieda vreští. "Even in 
Budapest, misery yells." Since poverty is under the sign of fatalism, there is no reason for the Slovaks to perceive it as a complex of inferiority as compared to the capital cities of the former Austro-Hungarian Empire. Moreover, poverty is perceived in religious terms as the very attribute of the spiritual superiority as abandoning ephemeral material things actually means assuming God's eternal spiritual values. Yet, it does not apply when it comes to family assets, where the myth of the prodigal son is reiterated, e. g.: Sk: Otec stiska a syn výska. "Father clamps and his son yells.", Čo otec nazhromaždil motykou, to syn rozhadzuje lopatou. "What father gathered with the hoe, the son shatters with the shovel."

On the other hand, Slovaks are perceived as greedy when it comes to eating to excess, e. g.: Sk: Najedol sa ako sedliak na Hody (na Štedrý večer, na Vianoce). "He ate like a peasant at the country wake (on Christmas Eve, at Christmas)." $c f$. Sb: Biće svašta kao i na Božić (Vuk, 17) "They will be full like at Christmas", Nije svaki dan Božić! (Vuk, 268) "Not every day is Christmas!". In this context, by generalization, the peasant becomes the image of the greedy, bad-mannered Slovak, which is in contradiction with the traditional image of peasants as a social category working hard to earn their living. As a rule, during feasts, people tend to eat to excess: Sk: Na fašiangy výskal, v pôste brucho stískal. "At the carnival he yelled, when fasting he clamped.", Na Vianoce po gágorce, na Vianoce plné hrnce. "At Christmas up to gag, at Christmas full pots", Do Vianoc haj, od Vianoc jaj. "Till Christmas it's happiness, after Christmas it's gloominess." cf. Sb: Vaskrsenije je ručak bez večere. "Easter is like lunch without dinner." (Vuk, 37, explanation: Valja da se misli prema Božiću, a osobito što se u početku proleća primaklo svašta: od stare godine se pojelo, do nove se još nije prispjelo). Vodenica koja melje Božiću kolače, neće Uskrsu pogače. (Vuk) "The water mill grinding the flour for Christmas krendels does not grind that much for the Easter pretzels.", Do Božića ni gladi ni zime! (Vuk, 72) “Till Christmas, you are neither hungry, nor cold."

\section{Family bounds}

The family relationships converge to the idealized image of mother. The Slovak mother is pictured as the most loving human being, adoring her kids: Každej materi jej decko najkrajšie. "For any mom, her kid is the most beautiful." cf. Sb: Svakoj majci je svoje dete najlepše (najdraže). "For any mom, her kid is the best (favorite).", Matka sladká, kto ju má. "Sweet is mom for the one who has her." cf. Sb: Blago majci koja te rodila. "Bless the mother who gave birth to you!", The Slovak mother is also the one who protects the weakest child the most: Najhoršie decko mater najviac $k$ prsiam tisne (najviac na rukách nosí, najviac $k$ sebe túli). "Mother hugs the worst child to her breast the most (holds the worst child in her hands the most, nestles the worst child to her breast the most)." 
Family relationships also entail respect and appreciation towards the male figure of the family, which ensures true family bounds over generations, e. g.: Ako ty dnes otcovi, tak tebe raz tvoj syn. "Like you behave to your father today, so your son will behave to you tomorrow." There are lots of family myths that are confirmed by the Slovak phraseology. For instance, daughters are expected to look after their parents when the latter are in need for help while sons are known to leave their parents once they get married, e. g.: Kto má dcéry má rodinu, kto má synov, má cudzinu. "The one who has daughters has a family, the one who has sons has strangers." cf. Sb: Ко има породицу моје ћерке, који има синове, има странца. Another myth consists in the fact that a woman cannot manage her household by herself: Žena bez muža ako záhrada bez opravy (ako záhrada bez plota). "A woman without a man is like a garden without repair (like a garden without a fence)." cf. Sb: Žena bez čoveka kao bašta bez popravke / kao vrt bez ograde. "A woman without a man is like a garden without repair (like a garden without a fence)."

\section{The eternal conflict}

The eternal conflict between a mother-in-law and her daughter-in-law or her son-in-law is captured in phrasemes suggesting the unnatural hatred between the members of the family as the very result of marriage. The son-in-law is often pictured either as a poor, helpless guy who is good for nothing (e. g. Sk: Prišiel nahý do doтu. "He came naked to our house.") cf. Sb: Došao je goli u kuću. or as an outcast who can hardly find his place in his wife's family (e. g.: Zat' je ostatná litera $v$ abecede. "My son-in-law is the last letter in the alphabet." cf. Sb: Druga violina "Second violin", Zadnja rupa na svirali. "The last hole in the whistle". The daughter-in-law is not easily accepted in her husband's family either and is always perceived as comparable to the Devil itself just like her mother-in-law: Sk: Svokra na nevestu a nevesta na svokru sa žaluje, a aký čert, taký diabol. "Mother-in-law complains about her daughter-in-law, and the latter complains about the former, as devilish the former, so is the latter." Yet, there is hope for mutual understanding provided the mother-in-law is wise enough to be good to her daughter-in-law: Sk: Každá svokra na nevestu zlá. "Every mother-in-law is evil to her daughter-in-law.", Bud' mamička dobrá, bude i nevesta. "Be a good mom, and so will be your daughter-in-law.", Bud' svokra dobrá, bude i nevesta. "Be a good mother-in-law, and so will be your daughter-in-law." cf. Sb: Svekrva se ne sjeća da je negda i ona snaha bila. (Vuk, 351) "A mother-in-law cannot remember what to be a daughter-in-law is like.", Tuđa majka zla svekrva. (Vuk, 405) "The other one's mom is a bad mom.". 


\section{Us vs. the others}

The axis us vs. the others becomes me vs. strangers. Thanks to the ritualized friendship (Dolník, 2015: 181), the outsider becomes a stranger, a guest. This is also the case of the relationship between mother-in-law and her daughterin-law or her son-in-law: the latter come from a different culture, they usually come from different geographical regions, they speak their own dialect, and they may embrace different religions and even different moral values. This is why a daughter-in-law or a son-in-law is originally perceived as an outsider, and it takes some self-sacrifice to prove that they are worth being treated as guests in their spouse's family. Thus, the newly married Slovak woman is ready to undertake her husband's family name and even to give her kids her mother-in-law's or father-in-law's first names just as a safe exchange coin for her being accepted and tolerated in her new family. Let us not forget that a Slovak woman's family name is always derived from a man's surname, to which they add the ending -ová, which is formally very similar to the possession adjective, hence the tendency to attach a possession meaning to the female surname. Mrs. Kováčová will be very much something like a woman belonging to Mr. Kováčc, almost an object the man can dispose of. This is the price the traditional Slovak woman had to pay from the very beginning once she got married: she had to undertake her husband's name so as to turn from a stranger to a guest in her own family. But things have definitely changed in the Slovak society lately, especially when it comes to Slovak women working abroad and preferring the male version of their surname just to avoid the so-called interferemes, i.e. the transcultural barriers due to the female gender markers (Pekarovičová, 2016: 53). In other words, the same Mrs. Kováčová will prefer to be Mrs. Kováč abroad or even in their native country as the Act on national language no. 270/1995 allows the Slovak female public personalities to use the male version of their surname. It simply confirms what Čmejrková says about gender: it is not just gender that matters, there are many other factors such as: the social position, the profession and its prestige, the context (whether public or familiar), the type of relations, which means that gender cannot be regarded as an independent constant (Čmejrková, 1995: 46).

The axis $u s v s$. the others may be quite ambivalent. On the one hand, the Slovaks tend to trace a demarcation line between $u$ s meaning family, people of the same nationality, religion, moral values or sexual identity, and the others meaning people outside their family, of a different nationality, religion, sexual orientation or sharing different moral values: Cudzi je cudzi a svoj je svoj. "Strangers are strangers, and kins are kins." cf. Sb: Od tuđega tuga bije (Vuk, 293) "Sadness coming from someone else hurts more.", Teško svuda svome bez svojega. (Vuk, 398) "It is hard to live anywhere without one's kins.", Tuđemu se pohvali, a svojemu prvo kaži. (Vuk, 405) "Praize yourself to strangers, but first tell it to your kins! “. 
On the other hand, Slovaks are friendly and tend to tolerate and to accept the others easily, they call themselves holubí národ as they consider themselves to be peace loving, tolerant and hospitable. This is why Kde na najedia štyria, naje sa aj piaty. "If there is enough food for four, there will be enough for the fifth, as well." cf. Sb: Gde ima za dvoje, ima i za troje. "If there is enough food for two, there will be enough for the third, as well." And this is why the Slovaks treat strangers as if they had been part of their family: Sk: Podal mu pomocnú bratskú ruku.."He gave him a helping brother-like hand." cf. Sb: Pružio mu je ruku prijateljstva. "He gave him a friend-like hand." In both Slovak and Serbian culture, interhuman relationships strongly depend on mutual respect, fidelity, reliability, helpfulness whenever needed (Sk: Dobrá studňa v suchu vodu dáva; dobrý priatel" v núdzi sa poznáva. "A good well gives water in the desert; a good friend gives help when one is in need." cf. Sb: Prijatelj se u nevolji poznaje. "A friend in need is a friend indeed."). In spite of their tolerance, the Slovaks paradoxically have lots of prejudices when it comes to trusting the closest beings, such as the dog, the horse, their own wife or the Gypsies: Sk: Psovi, konnovi a žene never; peniaze bez čitania neber. "Do not trust the dog, the horse and the wife; do not take money without first counting it.", Psovi, ked' spi, cigánovi, ked" slubuje, a žene, ked' plače never. "Do not trust the sleeping dog, the gypsy making promises and the crying woman!", Koho raz v cigánstve popadnú, tomu ani pravdu neuveria. "Whoever was once trapped in Gypsy like tricks will never trust them even when they tell the truth." cf. Sb: Ženu, pušku i konja može čoek pokazati, ali u naruč ne davati. (Vuk, 97) "Show your wife, your rifle and your horse, but don't give any of them!"

\section{Conclusion}

In conclusion, we can say that both the Slovak phrasemes as fixed, syntactically complex lexical units of idiomatic meaning, reflect the Slovak and Serbian prejudices in gender-related issues. Phrasemes mirror the ancestral wisdom as part of the Slovak and Serbian cultural identity consisting in mentefacts, sociofacts and artefacts, which means that they fully reflect convictions, opinions, stereotypes, myths.

\section{Bibliography:}

Jean Chevalier, Alain Gheerbrant, Dicționar de simboluri (București: Artemis, 1994).

Světla Čmejrková, Žena v jazyce in Slovo a slovesnost, 56 / no. 1 (Prague: Ústav pro jazyk český, 1995).

Juraj Dolník, Jazyk. Človek. Kultúra (Bratislava: Kaligram, 2010). 
Juraj Dolník, Kultúrny obraz textu in Jazyk a komunikácia v súvislostiach III (Bratislava: Univerzita komenského, 2011).

Juraj Dolník and col., Cudzost' - jazyk - spoločnost' (Bratislava: Iris, 2015).

Katarína Habovštiaková, Ema Krošláková, Frazeologický slovník. Človek a príroda vo frazeológii (Bratislava: Veda, 1996).

Ol'ga Orgoňová, Alena Bohunická, Cudzost' a rodová identita in Cudzost' - jazyk spoločnost' (Bratislava: Iris, 2015).

Đorđe Otašević, Frazeološki rečnik, online version: https://www.scribd.com/ document $/ 331691870 / \% \mathrm{C} 4 \% 90$ or $\% \mathrm{C} 4 \% 91$ e-Ota $\% \mathrm{C} 5 \% \mathrm{~A} 1$ evi $\% \mathrm{C} 4 \% 87$ Frazeolo\%C5\%A1ki-Re\%C4\%8Dnik-pdf, 1.10.2018.

Jana Pekarovičová, Rodové stereotypy $\mathrm{v}$ interdisciplinárnych a interkultúrnych súvislostiach in Jazyk a komunikácia v súvislostiach III (Bratislava: Univerzita komenského, 2011).

Jana Pekarovičová, Rod ako gramatická a sociálna kategória in Slovenčina (nielen) ako cudzí jazyk v súvislostiach II (Bratislava: Univerzita komenského, 2016).

Mile, Tomici, Dicționar frazeologic român-sârb (Timișoara: Uniunea Sârbilor din România, 2012).

Stefanović Karadžić Vuk, Srpske narodne poslovice, online version: https://www. bastabalkana.com/2015/11/srpske-narodne-poslovice-mudrosti-izreke-sintagme/, 1.10.2018.

\section{GENRE ET IDENTITÉ DANS LA PHRASEOLOGIE SLOVAQUE ET SERBE}

\section{Resumé}

Náš príspevok je založený na nerozlučitel’nom vzt’ahu medzi genderom, identitou a jazykovým determinizmom, ktoré sa dokonale odrážajú vo frazeológii. Metodologický prístup je odvodený z Dolníkovej teórie o kultúrnej identite ako súboru mentefaktov, sociofaktov a artefaktov. Mentefakty predstavujú myšlienky, názory, presvedčenia, hodnoty, predsudky, stereotypy a mýty týkajúce sa spoločenskej hierarchie, spravodlivosti, zmyslu života a smrti, morálky, vzt’ahu medzi jednotlivcom a skupinou, do ktorej patrí. Sociofakty predstavujú inštitúcie z hladiska sociálnej antropológie a kultúrnej sociológie, sú to štruktúrami pôsobiacimi v rôznych oblastiach spoločenského života. Artefakty predstavujú materiálne kultúrne konštrukcie ako súčast' civilizácie (Dolník, 2011: 57-61). V tejto rovnici sa jazyk ako súčast' kultúry a implicitne súčast' identity stane nástrojom, pomocou ktorého ludia môžu interpretovat' svet, v ktorom žijú, čo vedie k jazykovému determinizmu. Zložky kultúrnej identity sa navyše prekrývajú nielen so štádiami individuálneho jazykového vývoja, ale aj so samotnými etapami vývoja frazém. $\mathrm{Na}$ 
základe vzt’ahu medzi individuálnou identitou, kultúrnou kolektívnou identitou, jazykovým determinizmom a vývojom frazém, berúc do úvahy, že kultúrna pamät' zahíňa jazykovú pamät' (Dolník, 2010: 93), dá sa demonštrovat', že rodové otázky sa verne odrážajú vo frazeológii. Týka sa to aj slovenčiny, aj srbštiny ako slovanských flektívnych jazykov, ktorých frazeológia odráža prvky ich hrdosti a predsudkov v otázkach súvisiacich s genderom.

Klúčové slová: rod, gender, identita, mentefakty, sociofakty, artefakty. 